\title{
Laevadosin in Treatment of the Duchenne Type of Muscular Dystrophy: Preliminary Results of a Double-blind Controlled Trial
}

\author{
J. M. S. PEARCE,* M.B., M.R.C.P. ; S. S. GUBBAY,* M.B., M.R.A.C.P. ; JENNIFER HARDY,* M.B., B.S. ; \\ R. J. T. PENNINGTON,* B.SC., PH.D. ; D. J. NEWELL,* M.A., PH.D. ; JOHN N. WALTON,* M.D., F.R.C.P.
}

Brit. med. F., 1964, 2, 915-917

Many drugs have been advocated for the treatment of muscular dystrophy, but all have been shown eventually to lack any significant therapeutic effect. Among the remedies subjected to extensive clinical trials have been glycine, leucine, multiple vitamins, mixed amino-acids, vitamin $\mathrm{E}$ and its analogues, and anabolic steroids. The difficulties in the assessment of drug therapy in this condition are considerable. The enthusiastic response of a parent, distressed by the progressive disability seen in his child, to the offer of a new preparation renders more difficult a critical evaluation of the response to treatment. A good example of this situation is afforded by the claims for clinical improvement following uncontrolled treatment with anabolic steroids (De Toni, 1959 ; Bekény, Kraft, and Láng, 1959 ; Hantschmann, Matzelt, Mertens, and Nowakowski, 1962 ; Dowben, 1963). Only when subjected to a carefully planned controlled trial (Barwick, Newell, and Walton, 1963) was it demonstrated that two particular drugs of this type were of no more value during the period of assessment than a placebo.

During the past few years yet another drug has been introduced for the treatment of muscular dystrophy. The preparation, named Laevadosin, is a nucleotide-nucleoside mixture, and was first used by Beckmann (1959, 1964), who noted no functional improvement in patients with rapidly progressive muscular dystrophy with irreversible muscle damage, but benefit was derived from this treatment in other instances. The results of a course of Laevadosin therapy have been reported recently in six patients with the Duchenne type of muscular dystrophy and in one with the limb-girdle type (Thomson and Guest, 1963). In this trial the patients were used as their own controls, and the drug was given parenterally to each patient for approximately 40 days. The authors claim to have shown amelioration of the dystrophic process, as judged by increase in muscle power and by diminution in the activity of serum aldolase and transaminases. More recently, Guest and McLay (1964) claim improvement in 19 cases treated for between 5 and 28 months. These trials have been criticized as lacking control groups, and the disadvantages of using the patient as his own control have been clearly outlined (Lancet, 1963). We believed that a similar trial, rigidly designed and strictly controlled, was necessary before the widespread administration of this preparation could be recommended; we report below the preliminary findings of such a trial.

\section{Material and Methods}

The detailed administration of the trial was purposely designed to replicate closely that of Thomson and Guest (1963) so that valid comparison was possible.

Twenty subjects were selected, and 14 of these were ambulant when the trial began. All but one (a patient in the * From the Departments of Neurology and Child Health, Newcastle
General Hospital and the Royal Victoria Infirmary, Newcastle upon
Tyne. control group who died suddenly) completed the trial. All showed clinical stigmata typical of the sex-linked recessive Duchenne type of dystrophy and all had grossly increased serum creatine kinase activity (100 to 800 units). This enzyme was chosen to monitor the biochemical progress of the disease, as it has been shown (Pearce, Pennington, and Walton, 1964b) to be the most sensitive indicator of the dystrophic process currently available. The patients were initially divided into two groups : (1) treatment group, those receiving Laevadosin, and (2) control group, those receiving a placebo (oral calcium lactate, $300 \mathrm{mg}$. three times daily). The patients were allocated to the treatment or control group by a restricted randomization procedure which ensured equal numbers of ambulant patients and a close match in terms of age and degree of disability. The control group were not given inert intravenous infusions and intramuscular injections as it was felt that this was hardly justifiable; a similar plan was adopted by the Streptomycin in Tuberculosis Trials Committee of the M.R.C. (1948); it was discussed and approved by Bradford Hill (1963). In every other respect, and particularly in relation to periods of compulsory bedrest, the patients in the two groups were treated identically. The observer assessing muscle strength was totally unaware of the group to which each patient belonged. Drug administration was planned and carried out by an independent observer who did not participate in the pre- and posttreatment assessments. Serum creatine kinase estimations were carried out as described by Pearce, Pennington, and Walton (1964a). The results are expressed as $\mu$ moles of creatine formed per ml. of serum per hour at $37^{\circ} \mathrm{C}$.

Muscle power was assessed by methods essentially similar to those employed by Barwick et al. (1963). Ergometric measurements were made using a simple spring balance during maximal voluntary contraction of four muscle groups on each side-namely, the flexors and extensors of the elbow and the flexors and extensors of the knee; three separate measurements of the strength of each muscle group were made at each examination, the result recorded in pounds being the average of all three. The final figure recorded at each examination was the sum of the means obtained for each group. Power was also assessed according to the Medical Research Council (1943) scale in the flexors and extensors of the wrist- and elbow-joints, the abductors and flexors of the shoulder, the extensors of the knee, and the dorsiflexors of the ankle. A numerical recording (0 to 5 ) was obtained for each muscle tested, and the total "score" obtained at each examination was taken as the sum of the scores of the individual muscles tested.

\section{Details of Treatment}

Each child was put to bed and basal assessments were made of serum creatine kinase (C.K.) and of muscle strength by spring balance and by M.R.C. (1943) grading. The Laevadosin group of patients then received a five-day intra- 
venous infusion of the drug in saline. The doses given were $5,10,15,20$, and $25 \mathrm{ml}$. of Laevadosin on successive days. After the infusion the child was allowed up for 28 to 30 days and during this time received $5 \mathrm{ml}$. of Laevadosin daily intramuscularly. This month concluded, he was returned to bed and was given a further five-day intravenous infusion of Laevadosin, containing $10,20,30,50$, and $75 \mathrm{ml}$. of solution. After two to four days out of bed, so that muscular stiffness and the effects of any local bruising had worn off, muscle strength was again tested and recorded by the same observer.

The control group were treated in an identical fashion with bed-rest and muscle-strength measurements performed at the same time, but they received calcium lactate $300 \mathrm{mg}$. three times daily by mouth throughout the period of treatment. The patients were assessed in pairs, and, in case local bruising might reveal which patient had received the intravenous therapy, both children had their arms covered with dressings.

\section{Results}

Tables I and II show the results of testing muscle strength before and after treatment in the two groups of patients. The

Table I.-Muscle Power in Controls, Before and After Treatment

\begin{tabular}{|c|c|c|c|c|c|c|c|}
\hline \multirow{3}{*}{$\begin{array}{l}\text { Controls } \\
\text { Case } \\
\text { No. }\end{array}$} & \multirow{3}{*}{$\begin{array}{l}\text { Age in } \\
\text { Years }\end{array}$} & \multicolumn{4}{|c|}{ Spring Balance } & \multirow{2}{*}{\multicolumn{2}{|c|}{ M.R.C. Grading }} \\
\hline & & \multicolumn{2}{|c|}{ Before } & \multicolumn{2}{|c|}{ After } & & \\
\hline & & lb. & kg. & lb. & kg. & Before & After \\
\hline $\begin{array}{c}1 \\
2 \\
3 \\
4 \\
5 * \\
6 \\
7 \\
8 \\
9 \\
10\end{array}$ & $\begin{array}{r}11 \\
9 \\
8 \\
13 \\
14 \\
8 \\
6 \\
9 \\
6 \\
8\end{array}$ & $\begin{array}{l}16 \\
19 \frac{1}{2} \\
13 \\
77 \frac{1}{2} \\
10 \frac{1}{2} \\
48 \\
18 \\
38 \\
26 \\
28\end{array}$ & $\begin{array}{r}7.3 \\
8.8 \\
5.9 \\
35.2 \\
4.8 \\
21 \cdot 8 \\
8.2 \\
17.2 \\
11.8 \\
12.7\end{array}$ & $\begin{array}{l}18 \\
21 \\
10 \\
74 \frac{1}{2} \\
\frac{58}{17} \\
35 \\
26 \\
26\end{array}$ & $\begin{array}{r}8.2 \\
9.5 \\
4.5 \\
33.8 \\
26.3 \\
7.7 \\
15.9 \\
11.8 \\
11.8\end{array}$ & $\begin{array}{l}59 \\
50 \\
39 \\
68 \\
33 \\
64 \\
64 \\
64 \\
66 \\
64\end{array}$ & $\begin{array}{l}59 \\
50 \\
38 \\
68 \\
66 \\
64 \\
64 \\
66 \\
64\end{array}$ \\
\hline
\end{tabular}

* Died suddenly at home before completion of treatment.

Table II.-Muscle Power in Treatment Group Before and After Laevadosin Treatment

\begin{tabular}{|c|c|c|c|c|c|c|c|}
\hline \multirow{3}{*}{$\begin{array}{c}\text { Laeva- } \\
\text { dosin } \\
\text { Case } \\
\text { No. }\end{array}$} & \multirow{3}{*}{$\begin{array}{l}\text { Age in } \\
\text { Years }\end{array}$} & \multicolumn{4}{|c|}{ Spring Balance } & \multirow{2}{*}{\multicolumn{2}{|c|}{ M.R.C. Gradin }} \\
\hline & & \multicolumn{2}{|c|}{ Before } & \multicolumn{2}{|c|}{ After } & & \\
\hline & & lb. & $\mathrm{kg}$. & lb. & kg. & Before & After \\
\hline $\begin{array}{l}11 \\
12 \\
13 \\
14 \\
15 \\
16 \\
17 \\
18 \\
19 \\
20\end{array}$ & $\begin{array}{r}7 \\
5 \\
7 \\
6 \\
13 \\
10 \\
9 \\
11 \\
7 \\
7\end{array}$ & $\begin{array}{l}12 \\
36 \\
24 \\
19 \\
21 \\
31 \\
22 \\
14 \frac{1}{2} \\
43 \\
29 \frac{1}{2}\end{array}$ & $\begin{array}{r}5.4 \\
16.3 \\
10.9 \\
8.6 \\
9.5 \\
14.1 \\
10.0 \\
6.6 \\
19.5 \\
13.4\end{array}$ & $\begin{array}{l}10 \\
34 \\
28 \\
16 \\
24 \\
33 \\
17 \frac{1}{2} \\
11 \frac{1}{2} \\
34 \frac{1}{2} \\
29\end{array}$ & $\begin{array}{r}4.5 \\
15.4 \\
12.7 \\
7.3 \\
10.9 \\
15.0 \\
7.9 \\
5.2 \\
15.6 \\
13.2\end{array}$ & $\begin{array}{l}48 \\
66 \\
64 \\
64 \\
58 \\
64 \\
53 \\
38 \\
63 \\
65\end{array}$ & $\begin{array}{l}38 \\
68 \\
64 \\
64 \\
58 \\
65 \\
52 \\
36 \\
67 \\
65\end{array}$ \\
\hline
\end{tabular}

TABLE III.-Spring-balance Results: Analysed by Percentage Differences

\begin{tabular}{|c|c|c|c|c|c|}
\hline & & & & Laevadosin & Controls \\
\hline 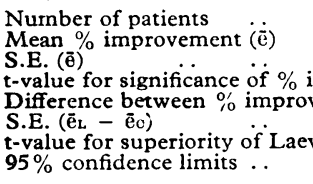 & 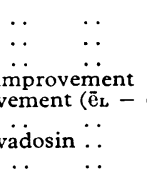 & $\begin{array}{l}\because \\
\because \\
\ddot{\mathrm{e} o j} \\
\cdots \\
\cdots \\
\cdots\end{array}$ & \begin{tabular}{l|}
$\cdots$ \\
$\cdots$ \\
$\cdots$ \\
$\cdots$ \\
$\cdots$ \\
$\cdots$
\end{tabular} & \multicolumn{2}{|c|}{ 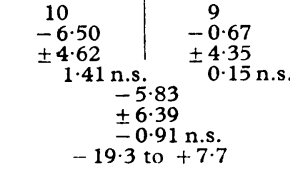 } \\
\hline
\end{tabular}

n.s. Not statistically significant at the $5 \%$ level.

TABLE IV.-M.R.C. Grading Results: Analysed by Percentage Differences

\begin{tabular}{|c|c|c|c|c|c|}
\hline & & & & Laevadosin & Controls \\
\hline 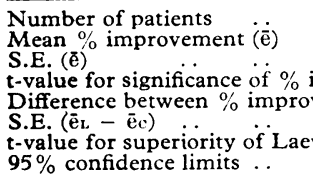 & $\begin{array}{l}\ldots \\
\because \\
\therefore \\
\text { improvement } \\
\text { vement }\left(\bar{e}_{L}-\right. \\
\ldots \\
\text { vadosin } \\
\ldots \\
. .\end{array}$ & $\begin{array}{c}\because \\
\because \\
\because \\
\therefore \\
\cdots \\
\cdots\end{array}$ & \begin{tabular}{l|}
$\ldots$ \\
$\cdots$ \\
$\cdots$ \\
$\cdots$ \\
$\cdots$ \\
$\cdots$
\end{tabular} & $\begin{array}{r}10 \\
-2 \cdot 30 \\
\pm 2 \cdot 27 \\
1.01 \mathrm{n.s} . \\
-2 . \\
\pm 2 \\
-7 \cdot 4 \\
-7.4\end{array}$ & $\begin{array}{l}\quad 9 \\
-0.11 \\
\pm 0.56 \\
\quad 0.20 \text { n.s. } \\
19 \\
46 \\
39 \\
+3.0\end{array}$ \\
\hline
\end{tabular}

10 patients given Laevadosin had a mean muscle strength of $25.2 \mathrm{lb}$. (11.43 kg.) before treatment and $23.8 \mathrm{lb}$. (10.8 kg.) after treatment. The nine controls gave corresponding figures of 31.6 lb. $(14.33 \mathrm{~kg}$.) before and $31.7 \mathrm{lb}$. (14.38 kg.) after treatment. The difference between the percentage improvements on Laevadosin $(-6.5 \%)$ and controls $(-0.7 \%)$ is not statistically significant (Table III). The results of M.R.C. grading measurements (Table IV) were similar to the muscle springbalance analysis, the mean percentage improvements being Laevadosin -2.3 and controls -0.1 . These changes are not significant.

Serial estimations of serum creatine kinase levels were periormed on all patients. These were carried out before treatment ; on days 3,5 , and 7 , covering the first intravenous infusion; weekly during the month of intramuscular injections ; and on days $34,35,37$, and 39 -that is, before, during, and after the second intravenous infusion. Creatine kinase levels were measured at the same time on patients in the control group. For convenience the average activities of this enzyme at different stages of the trial are grouped together in Table $\mathrm{V}$. The changes from the initial level occurring in the treatment and control groups are shown in Table VI. Difficulty was occasionally experienced in obtain-

TABLE V.--Serum Creatine Kinase Average Levels Throughout the Trial

\begin{tabular}{c|c|c|c|c} 
& \multicolumn{2}{|c|}{ Laevadosin } & \multicolumn{2}{c}{ Controls } \\
\cline { 2 - 5 } Days & No. of Patients & Mean C.K. & No. of Patients & Mean C.K. \\
\hline $1-3$ & 7 & 239 & 9 & 198 \\
$6-7$ & 9 & 175 & 6 & 126 \\
$14-20$ & 9 & 234 & 10 & 231 \\
$21-27$ & 7 & 275 & 9 & 266 \\
$34-42$ & 9 & 322 & 8 & 252
\end{tabular}

This table relates to all patients who had a C.K. reading in the particular period

TABLE VI.-Serum Creatine Kinase: Changes from Initial Level of Activity Noted at Successive Stages of the Trial

\begin{tabular}{|c|c|c|c|c|c|}
\hline \multirow{2}{*}{ Days } & \multicolumn{2}{|c|}{ Laevadosin } & \multicolumn{2}{|c|}{ Controls } & \multirow{2}{*}{$\begin{array}{l}\text { Difference } \\
\text { Between } \\
\text { Means } \\
\text { Laevadosin } \\
\text { Controls }\end{array}$} \\
\hline & $\begin{array}{l}\text { No. of } \\
\text { Patients }\end{array}$ & Mean C.K. & $\begin{array}{l}\text { No. of } \\
\text { Patients }\end{array}$ & Mean C.K. & \\
\hline $\begin{array}{c}6-7 \\
14-20 \\
21-27 \\
34-42\end{array}$ & $\begin{array}{l}7 \\
6 \\
6 \\
7\end{array}$ & $\begin{array}{r}-111 \\
-58 \\
+70 \\
-59\end{array}$ & $\begin{array}{l}6 \\
9 \\
8 \\
7\end{array}$ & $\begin{array}{l}-50 \\
-1 \\
-4 \\
-7\end{array}$ & $\begin{array}{l}-61 \\
-57 \\
+74 \\
-52\end{array}$ \\
\hline
\end{tabular}

ing adequate samples from some obese patients on the exact day specified; this is the reason why at certain stages of the trial (Table VI) results were not obtained for every case in the two groups.

\section{Discussion}

From the results presented it is clear that in the dose administered during a six-week period Laevadosin did not produce any observable clinical benefit when compared with a placebo. The parameters of improvement using a spring balance and M.R.C. grading are admittedly crude. Such measurements are prone to errors which may arise as a result of (1) partial failure of the child to co-operate fully ; (2) good co-operation in a child who is nevertheless generally unwell or tired from unrelated causes-for example, coryza; and (3) variation in the observer, including number preference. These are not serious criticisms of the methods used, since a fairly striking increase in muscle strength would be needed for a child to be improved in terms of improvement in motor skills and mobility.

It has been suggested on reasonable theoretical grounds that significant sudden diminutions of serum enzyme levels suggest amelioration of the dystrophic process. The results (Tables V and VI) obtained with serum C.K. are variable, with complete reversal of the effect of Laevadosin at 
days $21-27$, which subsequently reverses again at days 34-42. One child in the Laevadosin-treated group had an initial C.K. level of 700 units as compared with the next highest initial level in the whole series of 340 units; in his case there was a striking fall in activity during treatment and the enzyme has not subsequently increased to a figure comparable to the initial reading. If this one child with the highest initial level is excluded, each of the figures in the mean C.K. column (Table VI) becomes greater than the corresponding control figure-that is, unfavourable to Laevadosin (Table VII). Thus while at first sight the figures given in Table VI suggest that a greater fall occurred in C.K. activity during treatment in patients receiving Laevadosin, it will be seen from Table VII that this impression was false, being almost wholly due to the fall which occurred in a single case.

TABLE VII.-Serum Creatine Kinase: Changes from Initial Level of Activity, Excluding the Findings in One Patient Receiving Laevadosin

\begin{tabular}{c|c|c|c|c|c}
\hline \multirow{2}{*}{ Days } & \multicolumn{2}{|c|}{ Laevadosin } & \multicolumn{2}{|c|}{ Controls } & $\begin{array}{c}\text { Difference } \\
\text { Between } \\
\text { Means } \\
\text { Laevadosin - } \\
\text { Controls }\end{array}$ \\
\cline { 2 - 6 } & $\begin{array}{c}\text { No. of } \\
\text { Patients }\end{array}$ & Mean C.K. & $\begin{array}{c}\text { No. of } \\
\text { Patients }\end{array}$ & Mean C.K. & \\
\hline $6-7$ & 6 & -23 & 6 & -50 & +27 \\
$14-20$ & 5 & +32 & 9 & -1 & +23 \\
$21-27$ & 6 & +70 & 8 & -4 & +74 \\
$34-42$ & 6 & +20 & 7 & -7 & +27 \\
\hline
\end{tabular}

When the results for other individual patients are closely inspected there is a general trend in both control and treatment groups for the serum C.K. level to fall during the period of bed-rest and to rise subsequent to the mobilization of the patient. By the inspection of the individual differences it is clear that there is no statistically significant difference between the two groups of patients at any time. This could indicate that serum C.K. is too variable a measurement to demonstrate difference between the treatments, but it could also be interpreted as showing that Laevadosin produces no more diminution in serum enzymes-that is, improvement in the dystrophic process-than does the placebo-control therapy.

The results of the muscle-strength testing by spring balance (Table I) and by M.R.C. grading (Table II) have been subjected to statistical analysis (Tables III and IV). Each analysis is on a "within patient" basis. Absolute differences (not tabulated) and percentage differences have been calculated and the results are almost identical. The patients receiving Laevadosin deteriorated slightly; the controls remained unchanged, but the differences were not significant.

We have conclusively demonstrated that Laevadosin is not better than a placebo when administered in this dosage over a period of six weeks as recommended by Thomson and Guest (1963). This does not imply that the drug is without value. To establish the value of the preparation it is necessary to carry out a more prolonged trial, incorporating both longer periods of treatment and longer periods of follow-up. Such a trial is now in progress in this centre and will be the subject of a further report. Until this or a similar adequately controlled assessment has been reported we believe that there is no clinical indication for the routine administration of this nucleoside-nucleotide mixture to patients with muscular dystrophy.

\section{Summary}

Laevadosin, a mixture of nucleotides and nucleosides, when administered to patients with the Duchenne type of muscular dystrophy over a six-week period did not produce any observable benefits when compared with a placebo. The results were based on objective assessment of alterations in muscle power and changes in serum creatine kinase levels. The drug may be found to be of value after a more prolonged period of treatment and follow-up, but until the results of such an extended trial are known the routine administration of this remedy to patients with muscular dystrophy is not recommended.

We are indebted to Professor S. D. M. Court, Dr. G. Davison, and Dr. F. J. W. Miller, and to the staff of the Departments of Child Health at the Newcastle General Hospital and Royal Victoria Infirmary for allowing us to admit patients to their beds during the period of this trial and for their assistance. We are also grateful to $\mathrm{Mr}$. Wing and to Mr. Pool, of the pharmacy departments in the two hospitals, for their collaboration. Thanks are also due to Miss H. Caulfield and Mr. G. Brown for technical assistance. This work was aided by research grants from the Muscular Dystrophy Association of America Inc., the Muscular Dystrophy Association of Canada, and the Muscular Dystrophy Group of Great Britain. The Scientific and Research Subcommittee of the Royal Victoria Infirmary gave a grant towards the purchase of Laevadosin, and a proportion of the drug used in the early stages of the trial was supplied by Calmic Ltd.

\section{REFERENCES}

Barwick, D. D., Newell, D. J., and Walton, J. N. (1963). Neurology (Minneap.), 13, 12.

Beckmann, R. (1959). Arch. Kinderheilk., 159, 217.

- (1964). Rev. canad. Biol., 23, 77.

Bekény, G., Kraft, F., and Láng, S. (1959). Psychiat. et Neurol. (Basel), $137,193$.

De Toni, E. (1959). Clin. pediat. (Bologna), 41, 441.

Dowben, R. M. (1963). New Engl. F. Med., 268, 912.

Guest, K. E., and McLay, W. D. S. (1964). Brit. F. clin. Pract., 18, 395. Hantschmann, N., Matzelt, D., Mertens, H. G., and Nowakowski, H. (1962). Dtsch. med. Wschr., 87, 2619.

Hill, A. Bradford (1963). Brit. med. F., 1, 1043.

Lancet, 1963, 1, 1359.

Medical Research Council (1943). War Memo., No. 7, H.M.S.O., London.

- (1948). Brit. med. 7., 2, 769.

Pearce, J. M. S., Pennington, R. J., and Walton, J. N. (1964a). 7. Neurol. Neurosurg. Psychiat., 27, 1.

-

Thomson, W. H. S., and Guest, K. E. (1963). Ibid., 26, 111. 